\title{
The Royal Dinner Party Puri Anyar Kerambitan Tabanan: A Sustainable Cultural Tourism Attraction Based on Local Community
}

\author{
$1^{\text {st }}$ Ni Made Ruastiti \\ Arts Performance Dept. \\ Indonesia Institute Of Arts \\ Denpasar, Indonesia \\ nimaderuastiti@gmail.com. \\ $4^{\text {th }}$ Komang Shanty Muni Parwati \\ Hotel Management Dept. \\ International Bali Institute Of Tourism \\ Denpasar, Indonesia \\ komang.shanty@yahoo.com
}

\author{
$2^{\text {nd }}$ Gede Yoga Kharisma Pradana \\ Hotel Management \\ Dept.International Bali Institute Of \\ Tourism \\ Denpasar, Indonesia \\ yoga@stpbi.ac.id.
}

\author{
$3^{\text {rd }}$ I Gusti Ketut Purnaya \\ Hotel Management Dept. \\ International Bali Institute Of Tourism \\ Denpasar, Indonesia \\ purnaya@stpbi.ac.id
}

\begin{abstract}
The purpose of this research is to explore the aspects of sustainability of society in the Puri Kerambitan Tabanan. The cultural feast should be held with a traditional ceremony at Puri Kerambitan Tabanan. However, the Puri Kerambitan Tabanan often does cultural feast for tourists named 'The Royal Dinner Party'. This situation has risen problems to surrounding neighbour of Puri Kerambitan associated to The Royal Dinner Party. The question are : (1) how does The Royal Dinner Party form as a cultural and sustainable tourism attraction?; (2) What is the impact of the Royal Dinner Party at Puri Kerambitan Tabanan?

The Royal Dinner Party at Puri Kerambitan Tabanan was researched using qualitative methods. The primary data of the study was obtained through interviews and participatory observation at Puri Kerambitan Tabanan. For the sake of refinement of research result, secondary data was used through literature study. All data were analyzed using symbol theory, hegemonic theory and power of knowledge theory.

The result of the research shows that : (1) The Royal Dinner Party at Puri Kerambitan Tabanan is organized for the tourists in the form of dinner activity based on local wisdom. Tourists who arrived at Puri Kerambitan were greeted with great fanfare like royal guests. The dinner party event with the theme of 'grand guests' procession looks very interactive and different than dinner for tourists in general; (2). Specifically, the implementation of The Royal Dinner Party at Puri Kerambitan Tabanan has an economic impact, sekaa and patron client revitalization, increasing people's motivation to become tourism actors and preserving balinese cultural arts.
\end{abstract}

Keywords-The Royal Dinner Party, Puri Kerambitan Tabanan, Community Based Of Cultural Tourism Attraction, Sustainable.

\section{INTRODUCTION}

Bali Island is known for it's unique culture [2]. The uniqueness of Balinese culture cannot be separated from the diverse cultural traditions of indigenous peoples in the context of Balinese Hindu ceremonies [22]. The uniqueness of Balinese culture was born from a collective response to the whole range of Balinese ethnic group activities, especially when carrying out social activities based on customs. Almost every Balinese traditional activity involves ritual, art facilities and infrastructures that are revealed specifically as part of the totality of a series of social activities. The series of Balinese traditional activities are institutionalized sustainably across generations cannot be separated from the role of the banjar and the position of Puri as the center for preserving Balinese culture and empowering local communities in Bali. From the two cultural institutions, the Balinese life continues to be harmonious and stable in a sustainable manner. However, since the island of Bali was known as a tourist destination in the 1920s, Balinese life experienced many changes [2].

The variety of social changes in Balinese group occurs along with the progressive development of the Bali tourism industry. The number of visits from extraordinary tourists to Bali after the PATA conference in 1974 further increased the chances of accelerating tourism development and changing the orientation of the local communities in culture [22]. Opportunities from the Bali tourism development have impacted a lot of the changes in irrational thinking to be more rational [10]. Thus global opportunities through Bali tourism have contributed to changes in Balinese culture. The interaction between tourists and Balinese people is unconsciously changing various aspects of the culture in the local communities life.

Tourism development can increase financial income and individuality through the demands of creativity and professionalism [4]. The development of Bali tourism also turned out to have provided opportunities for the arts to appear in the interests of tourism [22]. The lively phenomenon of Balinese culture commodification for tourism seems to be in line with the financial benefits gained by Balinese as tourism agents. Multiple financial benefits from every action and reaction of tourism actors in Bali tourism have become the point of enthusiasm and the main motivational factors.

The orientation of people's lives becomes more materalistic in line with the times. Thus the life of Balinese 
people has changed since the rapid development of world tourism [24]. Correspondingly, Bali's public relations in the banjar are more stretchable and the position of Palace as a centre for Balinese ethnic and social activities is increasingly marginalized. The situation is accordance with emphasizes of Bali tourism development has had a significant influence on social life in Bali [22].

Marginalization of the palace position in the midst of the Balinese dynamics life in the tourism sector has an impact on the crisis of Puri as a centre for indigenous empowerment and cultural activities. Many palace tried to improve the situation and make prudent decisions by commodifying culture, but the fate was similar to Puri Anyar Kerambitan Tabanan in 1961 whose position had deteriorated due to a financial and asset crisis for ritual purposes, puri maintenance and empowerment of local communities.

It is interesting to note that after 1961, Puri Anyar Kerambitan Tabanan succeeded in developing the potential of cultural tourism in The Royal Dinner Party which attracted tourists. Similarly, the commodification of Palace culture in Bali has been successfully designed and offered, including by Puri Pemecutan, Puri Peliatan and Puri Ubud [14]. But no one has raised the theme of 'royal guest welcome procession' in a lively and based local community such as at Puri Anyar Kerambitan Tabanan for tourism.

Generally, cultural parties should only be held in the context of Balinese traditional ceremonies at Puri Anyar Kerambitan, Tabanan. However, Puri Anyar Kerambitan often holds cultural parties for the arrival of tourists known as 'The Royal Dinner Party' on sustainability. This situation has raised several issues regarding the relationship between Puri Anyar Kerambitan and the implementation of The Royal Dinner Party which can be formulated : 1) What is the form of the Royal Dinner Party Puri Anyar Kerambitan Tabanan as a sustainable cultural tourism attraction?; 2) What are the implications of the Royal Dinner Party Puri Anyar Kerambitan Tabanan? The solution of the two problem formulations in this study are expected to explain the sustainability aspects of The Royal Dinner Party in the Kerambitan Tabanan.

\section{RESEARCH METHODS}

It was conducted at Puri Anyar Kerambitan, Tabanan Bali. Puri Anyar Kerambitan, Tabanan Bali was chosen as the research location because only Puri Anyar Kerambitan, Tabanan Bali has a 'royal dinner party' as cultural tourism tour package and it is still sustainable. A field study of the royal dinner party at Puri Anyar Kerambitan, Tabanan has been done for thirteen years. The stage of the field study was carried out by conducting a one-year preliminary study on three different palaces in Bali that successfully developed a cultural tourism tour package for one year. Based on the results of the feasibility study, Puri Anyar Kerambitan Bali was chosen to continue at the field study stage and analyze data for approximately twelve years.

The Royal Dinner Party Puri Anyar Kerambitan, Tabanan phenomenon has been completed with qualitative methods. Qualitative methods are chosen based on the main research problems that require an understanding of quality data sets. Qualitaive method has relevance in finding data on complex reality, natural setting, dynamic in interaction and social experience [11].

Qualitative methods are suitable for use in the field research in natural settings, according to the research on The Royal Dinner Party Puri Anyar Tabambitan Kerambitan performed without any intervention on the practice of informants. In addition, using qualitative methods in a naturalistic manner is more likely to look for understanding of data in a reflective way related to research problems.

Qualitative methods related to Puri Anyar Kerambitan's Royal Dinner Party, Tabanan are applied inductively descriptive. During the research process, the theoretical foundation is used to guide, emphasize the focus research and reveal the reflectivity of the data set. All data in this research were obtained through library studies, interviews and observations at Puri Anyar Kerambitan, Tabanan. Primary data on the Royal Dinner Party Puri Anyar Kerambitan, Tabanan was obtained directly by applying purposive sampling technique at Puri Anyar Kerambitan, Tabanan.

Purposive sampling is a sampling technique with certain considerations [11]. The main consideration of the selection and determination of informants are based on capability and a list of names of informants recommended by the base informant to obtain primary data. As data obtained directly, primary data is analyzed using the theory of practice, hegemony and power of knowledge. Optimization of the analysis uses secondary data sets.

Secondary data from this research were obtained through the study of literature on books on tourism, culture and related research results. The secondary data sources can be in the form of company records or documentation, government publications, industry analysis by media, websites from the internet sources [6].

\section{RESULTS AND DISCUSSION}

The results of research on the Royal Dinner Party Puri Anyar Kerambitan, Tabanan were held on sustainable with local community power for tourism purposes through the implementation of a local wisdom-based dinner party. The implementation of the Royal Dinner Party Puri Anyar Kerambitan, Tabanan has implications for local tourism actors. The specifications can be listened to as follows :

\section{A. The Royal Dinner Party as a Cultural Attraction in The Puri Anyar Kerambitan, Tabanan.}

The Royal Dinner Party Puri Anyar Kerambitan Tabanan is carried out based on local wisdom. Local wisdom is the source of every action in the performance of The Royal Dinner Party Puri Anyar Kerambitan Tabanan. Knowledge that correlates with power structures can influence social action [3]. The base of local wisdom as a form of social action for tourism in The Royal Dinner Party Puri Anyar Tabanan scattering cannot be separated from the decision of Puri Anyar Kerambitan Tabanan family as a local elite who has the power to organize and manage tourism products in Puri Anyar Kerambitan Tabanan. The characteristics of tourism products 
are designed in such a way based on local wisdom by the family of Puri Anyar Kerambitan Tabanan as a tourist through the development of a palace culture has the potential to become a tourism capital. The development of cultural capital that has been successfully developed by the actors has strengthened the characteristics of tourism products. Bourdieu argues that cultural capital can strengthen social practices [7]. As the practice of cultural commodification in The Royal Dinner Party Puri Anyar Kerambitan Tabanan is able to be held in a large and festive manner to the use various attributes of the Kerambitan palace culture as an identity and reinforcement of the attraction of tourism event.

The special atmosphere in the Royal Dinner Party Puri Anyar Kerambitan that fascinated the temporary changes of the tourists habitus was inseparable from the peculiarities and effects of the cultural authenticity aspects of Puri Anyar Kerambitan Tabanan as cultural capital. Under these conditions, there has been a conversion of cultural capital into economic capital in the tourism sector. Capital conversion is a transfer of certain capital through capital exchanges and changes in capital allotment in certain domains [7]. The various cultural tourism attractions of Puri Anyar Kerambitan Tabanan as cultural tourism products that still have a palace cultural identity for tourism are very synonymous with the procession of welcoming royal relatives as honored guests at Puri Anyar Kerambitan. Giving the status of institutional superiority to tourists who can provide a sensation of satisfaction and raise prestige is expected to foster a sense of love for the cultural palace want to provide support and strengthen the superiority of the palace structure.

The inauguration process of the social power class structure requires accommodative action and adequate participation in providing support for actions [1]. The act of cultural commodification is a form of courage from the Puri Anyar Kerambitan Tabanan in responding to the opportunities and challenges of the presence of tourists in Tabanan, Bali.

The tourists as participants who came to attend The Royal Dinner Party Puri Anyar Kerambitan Tabanan were welcomed as like royal guests. Formation of symbolic images from the special welcome is an excellence prestige of tourism products for tourists who are considered to be able contribute to institutions through cultural promotion actions. The act of promoting culture and cultural preservation behind the implementation of The Royal Dinner Party Puri Anyar Kerambitan Tabanan is the point of the interests as the holders of power to achieve a significant response in the preservation of power structures amid social changes. Image formation through the management and accuracy of social practices is needed by the power holders to maintain and enforce power [8]. The establishment of the image of Puri Anyar Kerambitan Tabanan as a cultural tourism attraction has begun since the series of welcoming processions to tourists as special guests at The Royal Dinner Party Puri Anyar Kerambitan Tabanan. The process can be listened to as follows.

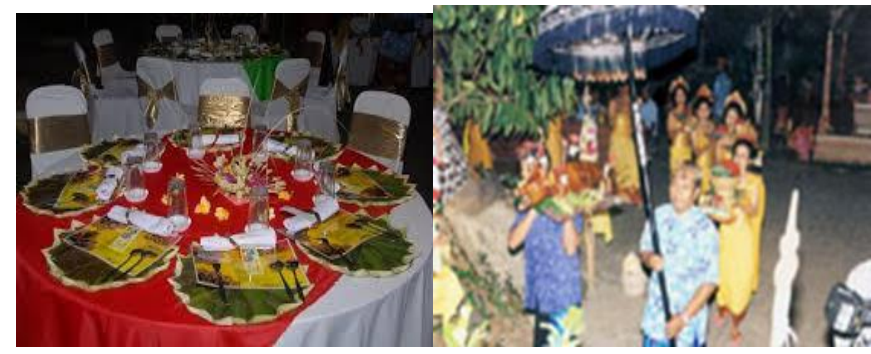

Photo 1. Dinner Process of Puri Anyar Kerambitan Tabanan (Doc. Ruastiti, 2007; 2010).

Based on photo 1. above it can be seen they wants to highlight the Balinese food and decoration components, so that the choice of food dishes and food processions is specially arranged with a predominant pattern of Balinese cultural identity. All cultural symbols in the significance of cultural tourism attractions are very familiar with the palace and the community as tourism actors. Symbolic diversification is strongly related to power [3]. Tourists as signifiers still recognize it that all cultural symbols in strengthening cultural tourism attractions in Puri Anyar Kerambitan Tabanan are still similar to the various symbols of palace culture for cultural interests. The relationship is similar to concerning social practice, namely practice through involving significance in the relationship between signified and signifier [25]. However, the atmosphere of excitement from signified manifestations in a series of cultural tourism attractions has been prepared for tourism. Not only festive, the event with the theme of welcoming the royal guests was held interactively with the language of motion and foreign languages. Symbolic separation between cultural tourism attractions and cultural ceremonies for royal relatives that have been carried out an impact on opening up access to capital for palace's culture in the tourism sector.

In order to optimize the attractive dinner activities for tourism, Puri Anyar Kerambitan involves a lot of indigenous people by providing a great opportunity to members of the Kerambitan community group to be involved in presenting large-scale cultural tourism attractions.

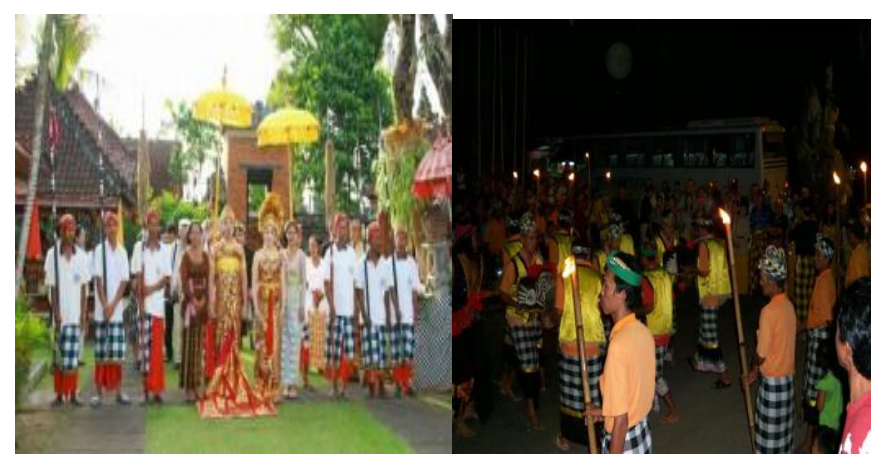

Photo 2. Puri Anyar Kerambitan peoples and Cultural Tourism Attractions

(Doc. Yoga, 2010; 2012). 
Based on photo 2 above, it can be observed the cultural tourism attraction of Puri Anyar Kerambitan Tabanan involves many people as tourism actors. The most tourism actors are indigenous people from Tabanan, who have a close relationship with Puri Anyar Kerambitan Tabanan. With relationships and knowledge, a group of people can be able to determine the face of civilization [3]. The social power relations between Puri Anyar Kerambitan Tabanan and tourism actors from members of the Kerambitan community has resulted in the characteristics of cultural tourism attractions as tourism products are very synonymous with the Puri Anyar Kerambitan Tabanan culture. It should be noted that the dominance of community participation members in Kerambitan as tourism actors is not based on coercion but rather on the interests of idealism. Ideological interests are a prerequisite for strengthening social actions to achieve common goals [1]. Economic motives and cultural aspects are the foundation of the tourism actors relationship with Puri Anyar Kerambitan Tabanan. The relation between cultural capital, social capital and economic capital has an influence in a realm of life in social practice [7]. The social capital and cultural capital in The Royal Dinner Party Puri Anyar Kerambitan Tabanan seemed to unite involving members of the Kerambitan community as a lot of indigenous people who wanted to display and develop the potential of cultural tourism in Puri Anyar Kerambitan.

As a large-scale tourism spectacle, Puri Anyar Kerambitan Tabanan cultural tourism attraction is displayed in a large place, precisely on the front yard of Puri Anyar Kerambitan Tabanan, jaba and innards which already has Balinese architecture. All actors try to integrate cultural symbols in performing arts activities, making dishes and traditional Balinese snacks for the special image of Puri Anyar Kerambitan Tabanan cultural attractions in the tourism context. Symbolic imagery can be effected through power and knowledge [8]. The privilege of cultural tourism attractions was optimized by involving 300 members of the Kerambitan community as tour operators who were handled by the procession coordinator, the art and procurement coordinator, entertaining organizer, decorator and security coordinator. The selection of the event coordinators was carried out by the Puri Anyar Kerambitan family based on consideration of the genealogical relationship between experience and knowledge about culture, Puri Anyar Kerambitan and Tourism. These considerations emphasize that a group of people become able to have power with knowledge. In other words, the coordinators of The Royal Dinner Party Puri Anyar Kerambitan Tabanan through their knowledge of culture, Puri Anyar Kerambitan and Tourism are able to become power holders in managing and organizing directly from cultural tourism attractions of The Royal Dinner Party Puri Anyar Kerambitan Tabanan to build the feel of a very memorable program for tourists.

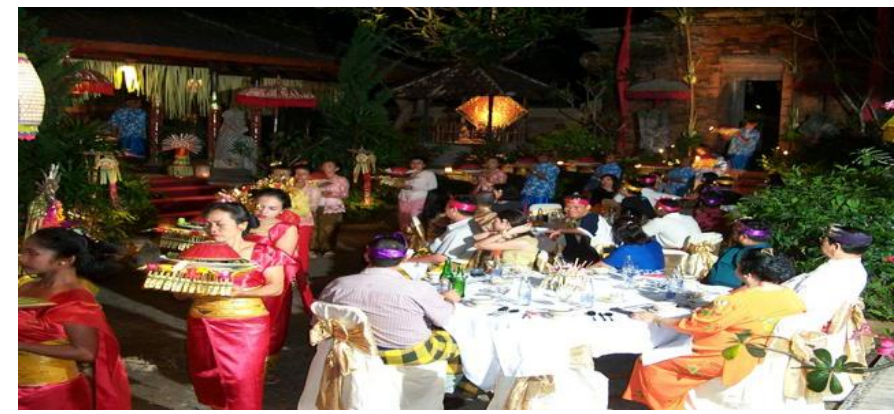

Photo 3. Tourists and Bali Cultural Tourism Attractions at The Royal Dinner Party Puri Anyar Kerambitan Tabanan

(Doc. Yoga, 2012).

Photo 3 above shows, there are Balinese cultural attractions for tourists. Many tourists seemed stunned and enjoyed the atmosphere of The Royal Dinner Party Puri Anyar Kerambitan Tabanan which was filled with symbols of Balinese culture. A variety of cultural symbols on clothing, decorations, performances and food cannot be separated from the aspect of integrity in the sense of beauty as cultural tourism attractions Puri Anyar Kerambitan Tabanan. Symbolic of beauty can cause a reaction [16]. Positive impressions as reactive potential often appear along with the development of the dinner party meaning when enjoying entertaintment during a dinner at Puri Anyar Kerambitan Tabanan among tourists. The meaning does not escape the influence of power and knowledge of morals, norms and values [8]. Therefore, the reaction and positive impression of tourists can mean that The Royal Dinner Party Puri Anyar Kerambitan Tabanan is not spared from the view of tourists that cultural tourism attractions are worth and according to their tastes.

Entertantment during dinner is the third stage of a series of cultural tourism offerings in The Royal Dinner Party Puri Anyar Kerambitan Tabanan. In consensus, the series of The Royal Dinner Party Puri Anyar Kerambitan Tabanan began with the stages of welcome dinner, pre-dinner entertaining, entertaining during dinner and entertainment after dinner.

\section{Entertainment Welcome Dinner}

Entertaintment Welcome Dinner is a stage where cultural tourism attractions are displayed to tourists when they arrive at Puri Anyar Kerambitan Tabanan, precisely at Jaba side of the Puri Anyar Kerambitan Tabanan for 30 minutes. There is a treat for the pendet dance and a series of commodification forms from the symbolic ceremony to the temple which has been embellished in order to the entertaintment welcome dinner at Puri Anyar Kerambitan Tabanan. Pendet dance at the Royal Dinner Party Puri Anyar Kerambitan was danced in pairs wearing prada fabric, kemben and scarves. 


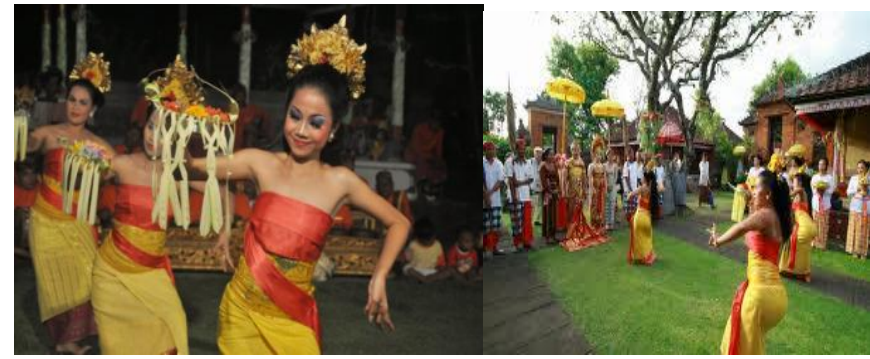

Photo 4. Pendet Dance at The Royal Dinner Party Puri Anyar Kerambitan Tabanan

(Doc. Ruastiti, 2012).

Based on photo 4. above, the dance using yellow prada fabric, red scarf, red color and carrying bokor is intended to tourists at The Royal Dinner Party Puri Anyar Kerambitan Tabanan. The duration of the show is shorter than the pendet dance for traditional ceremonies, but it's not to the extent of losing the sequence of movements. Changes in the composition of cultural attractions into cultural tourism attractions in Puri Anyar Kerambitan Tabanan show that commodification symptoms. Commodification involves modifying some components of the noun form based on the state of the environment into more valuable products or selling value [24]. Where under these conditions, the desire of tourists and the wishes of the Puri Anyar Kerambitan Tabanan family is the main base of conformity for the conduct of commodification practices.

As a commodification of culture, the form of the ceremonial procession for tourism is carried out in sequences by carrying gebogan, spears and banners from the place of ceremony accompanied by the gamelan sound towards Puri Anyar Kerambitan Tabanan. The significance of cultural attributes appear to be the same as traditional ceremonial processions, but the manifestation of the signified has undergone a change of sacred meaning into decorative.

The commodification of the ceremonial procession for tourism in the Royal Dinner Party Puri Anyar Kerambitan Tabanan is an imitation of mekiyis which has been neatly arranged for the wishes of the Puri Anyar Kerambitan Tabanan family for tourists. The influence of the Puri Anyar Kerambitan Tabanan family's power seems to be so great in determining the format of event activities and tourist attractions. As the existence of a power is capable of warning, limiting and repositioning personal physical [3]. Order in the tourism event is a proof of power that has influenced the performance of aesthetic forms from the Puri Anyar Kerambitan Tabanan cultural tourism attractions. Therefore, the aesthetic aspects of cultural tourism attractions are superior to the essence of Balinese ceremonies at The Royal Dinner Party Puri Anyar Kerambitan Tabanan for tourists.

Overall, a series of event processions before the predinner entertaining stage confirms the significance of grandeur of Puri Anyar Kerambitan Tabanan as well as the magnitude of the form of respect for tourists as special guests of the king. In the first appearance of the predinner entertaining series, Balaganjur attractions were held. Balaganjur as a traditional Balinese orchestra favored by the Puri Anyar Kerambitan Tabanan family is displayed as a form of excitement as well as the excitement of some actors for the presence of special guests.

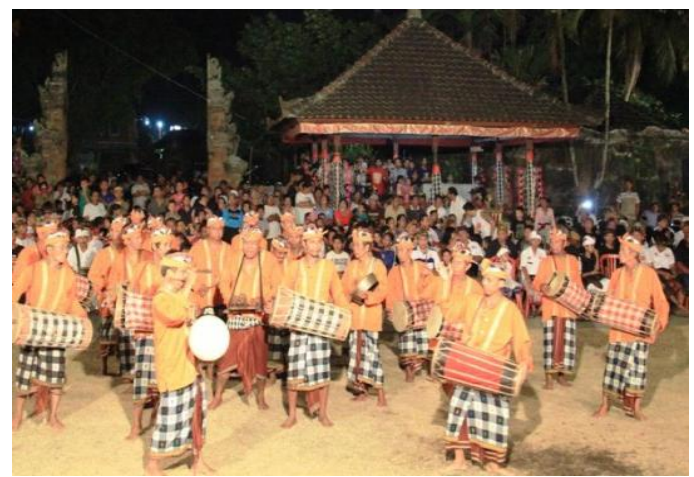

Photo of 5 Balaganjur at The Royal Dinner Party Puri Anyar Kerambitan Tabanan

(Doc. Ruastiti, 2013).

Photo 5 above shows the Balaganjur attraction scene was shown in a mass fashion by wearing a orange safari, kamen and black-white saput in uniform. The Balaganjur attraction was performed by more than 6 people with ceng-ceng kopyak, kendang cedugan, kajar, kempli, big gong, kempur and pemade as musical instruments. The appearance and sound performance of the various percussion combinations in Balaganjur which are played in various tempo have been considered to strengthening the atmosphere of grandeur and dignity of The Royal Dinner Party Puri Anyar Kerambitan, Tabanan.

The line of spears and umbul-umbul are the second group in the ceremonial procession series of The Royal Dinner Party Puri Anyar Kerambitan Tabanan for tourism. This procession is presented by the actors who use the headwear, shirt, kamen and saput similar to the symbolic attributes of Balinese traditional clothing when mekiyis by leaving an element of sacredness. The loss of the mystical sacrament is an indication of the civilization progress [26]. Likewise in the next line such as keben ranks which are placed third after the line of spears and banners are no longer related to the source of mystical power, so that cultural tourism attractions can be accepted by all tourists. Especially, tourists who are towards progressive oriented and they dont have interest in preserving culture can be a guest of the king's honor and enjoy the grandeur of Puri Anyar Kerambitan Tabanan.

At the keben line, there were around 20 women from the neighborhood of Puri Anyar Kerambitan Tabanan. The procession was carried out by the women by upholding the same box of woven bamboo over the head without the offerings by walking hand using white kebaya clothes, batik cloth and orange scarves. The ranks of the women were also involved in the embassy. Maleladan is a 
long line group of around 25 women who walk while carrying a series of flowers and fruits with an average height of $50 \mathrm{~cm}$.

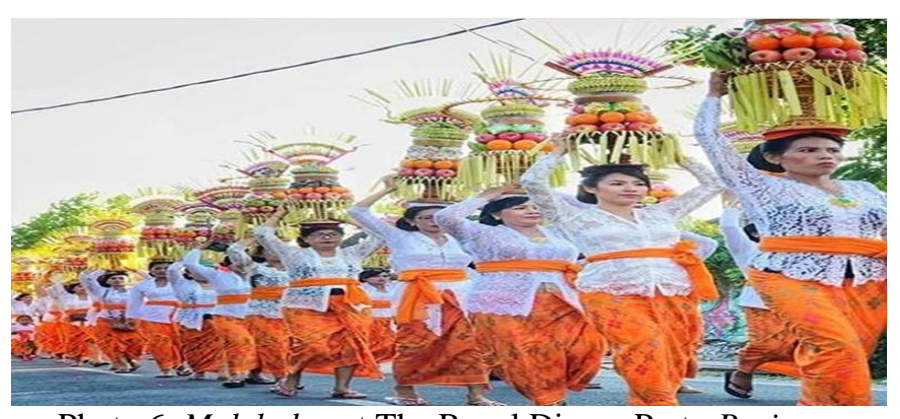

Photo 6. Maleladan at The Royal Dinner Party Puri Anyar Kerambitan Tabanan

(Doc. Ruastiti, 2013).

In photo 6 above, it can be observed about the line of women carrying the gebogan in The Royal Dinner Party Puri Anyar Kerambitan Tabanan. Starting from cosmetology, clothes, the high similarity of gebogan and neatness when walking hand is very much considered by the Puri Anyar Kerambitan Tabanan. The authority of supremacy of the palace power in that state as a central role in arranging and determining the qualifications of the performance of the ceremonial procession for tourism. Authority is a point for truth [3]. Enforcement of authority can be a way of achieving recognition, approval and social compliance. Approval of members of the Kerambitan community at Tabanan as a form of social recognition is realized in the form of understanding and orderliness during the implementation of tourism activities. Approval and understanding of the subordinate class is a prerequisite for the norm of social order in maintaining social system [5]. Practicing orderliness during the procession of the event manifests in a neat pattern. The neatness and uniformity of the appearance of the perpetrator's clothing has become a discretionary aspect in the aesthetic composition of cultural tourism attractions. Discretion shows that, there is a combination of different elements in order to achieve integration with integrity [15]. Discretionary conditions were also implemented on the aesthetic composition of each type of line group procession for the tourist in The Royal Dinner Party Puri Anyar Kerambitan Tabanan.

The Entertaintment Welcome Dinner was closed by tourist attractions from the Tektekan and Barong Ket. The Tektekan sequence is displayed in the fifth row sequence in a series of processions for the entertaintment welcome dinner. As a gathering of procession attraction for welcoming special guests, the Tektekan sound blossomed when as many as 50 men beat kentongan tools made of bamboo.

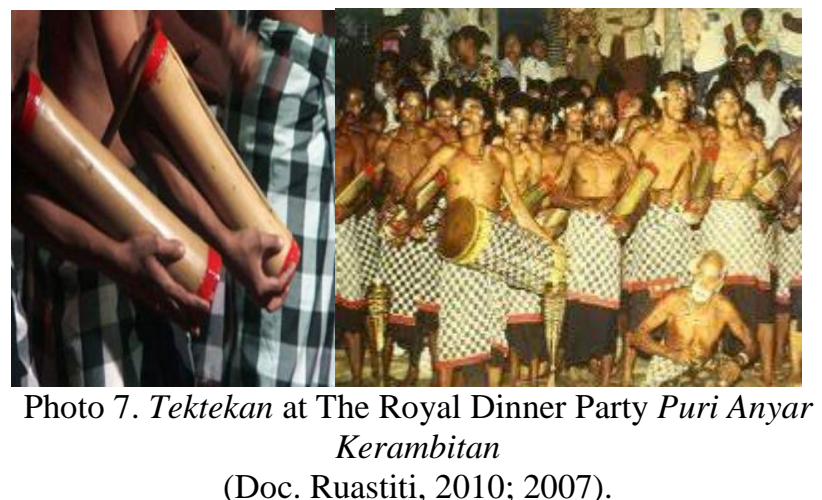

In photo 7 above, Tektekan has the same shape as the kentongan tool. The totality of Tektekan sounds for tourism means seriousness in celebrating for the death of the social ugliness. Power and knowledge relations can change the meaning of action [12]. Relations between members of the Kerambitan community and the Puri Anyar Kerambitan Tabanan family in the common interest of the tourism sector have reached a consensus on the changing meaning of the designation from the Tektekan symbols in the cultural context as a form of the source expulsion of social disaster into a celebration of the death of social ugliness when carried out in a The Royal Dinner Party Puri Anyar Kerambitan Tabanan. At the entertaining welcome dinner stage, the roar of the sound from Tektekan melody seemed to synergize with the Ballaganjur's voice in order to accompany and enliven the procession group for welcoming special guests.

Barong Ket is placed in the last procession of the entertaintent welcome dinner procession. Barong Ket symbolically has a red face and four legs. Signified from Barong Ket as a mythological creature. That is feared because it has extraordinary magical power and worshiped by Balinese group because it often protects members of social groups who behave well.

The power can be manifest in the form of oppression, prohibition and social restrictions [8]. The magical power of Barong Ket in the narration of Calonarang's story sided with the owner of exclusive morality and social restrictions based on normative construction that is of good value for the maintenance of social integrity and sustainability. The act of oppression as a form of power from the mythological creature with the red and spooky face follows is done directly only to the source of social havoc that can damage the integrity of a community as a manifestation of social justice. 


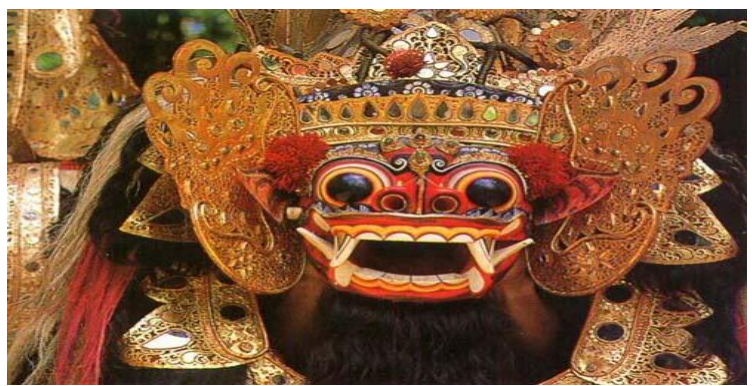

Photo 8. Barong Ket At The Royal Dinner Party Puri Anyar Kerambitan Tabanan

(Doc. Yoga, 2013).

In photo 8 above, the appearance of the form of Barong Ket. The appearance of Barong Ket was shown to tourists statically until all tourists were ready to step in the PreDinner Entertainment stage.

\section{Entertainment Pre-Dinner}

In the Pre-dinner Entertainment, the performance of Tektekan Calonarang performance was enlivened it for 60 minutes. Pre-dinner Entertaintment is the second stage of all cultural tourism attractions. The pre-dinner service was held on the front yard of Puri Anyar Kerambitan Tabanan during entertainment dinner not yet prepared for tourists. Calonarang performance on The Royal Dinner Party Puri Anyar Kerambitan Tabanan is a cultural tourism attraction that uses the Calonarang story with Tektekan music accompaniment. The Calonarang show is known to be attractive as tourist entertainment because there are unusual demonstrations of immunity from the dancers. In general, the dancers' bodies will be injured when exposed to sharp weapons such as keris. However, the opposite incident became a phenomenal attraction and seemed to have seized a lot of attention from tourists as spectators. Knowledge relations can generate power [8]. Mastery of the knowledge of dancing which is related to the religiosity of mythological knowledge in the Calonarang story has produced a special power effect for deepening the role character that has succeeded in strengthening the performance of cultural tourism attractions to be spectacular.

Calonarang character in the Calonarang story represents crime. The crime was interpreted based on the mastery of the Calonarang figure on witchcraft that had been wrongly applied. Knowledge always has a power effect [13]. The manifestation of magical power from Calonarang in the performance is realized in the form of magic as an accumulation of mastery over witchcraft. The application of witchcraft which is considered mistake by the public in the performance gets the power defiance show by the dancers in a way of stabbing Calonarang character with a keris as a form of social protest for the over magical actions. However, Calonarang's magic has made all the efforts of the keris dancers in vain until the Barong Ket arrives. When Barong Ket was present before the tourists, the dancers instantly displayed ngunying as a cultural tourism attraction.

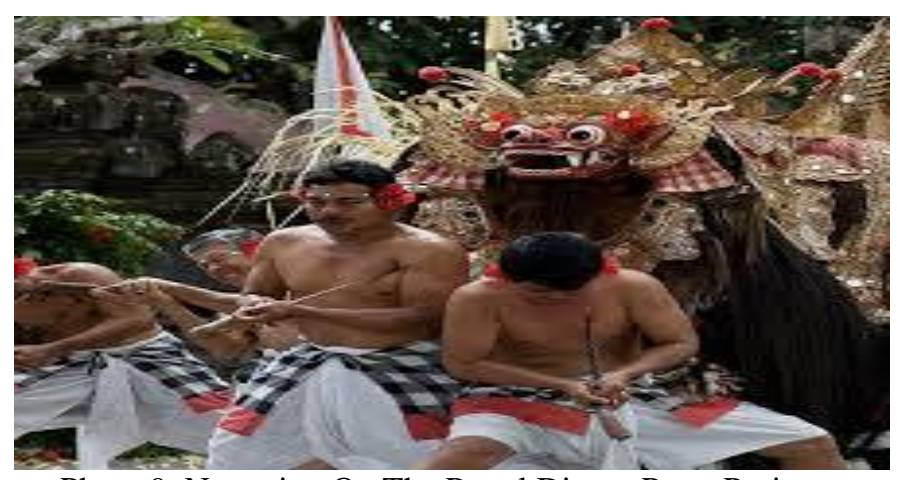

Photo 9. Ngunying On The Royal Dinner Party Puri Anyar Kerambitan Tabanan

(Doc. Yoga, 2010)

Based on photo 9 above, ngunying is a scene of dancers piercing themselves with a keris. Cultural tourism attractions from ngunying are located on the scene of self-sacrifice, but none have suffered injuries since the presence of Barong Ket as a symbol of dharma as the truth in staging. Truth is a power base [3]. Ngunying in the Calonarang performance can be interpreted as a form of protection of dharma as truth, thus the manifestation of the presence of Barong Ket when it can be interpreted as a symbol of social protection that irrationally saved the dancers from dangerous actions through the power of self-immunity that appears suddenly. The symbol of dharma relates to the symbol of social protection is the source of social power in ngunying. The scene was performed attractively by the dancers until Barong Ket defeated Calonarang. Calonarang's defeat was welcomed by the dancers by playing Tektekan instrument to expel Calonarang. When listened chronologically, the structure of the Calonarang performance on The Royal Dinner Party Puri Anyar Kerambitan Tabanan consists of seven scenes.

Scene I : It is told that a temple priest from the Erlangga Kingdom headed for the intersection of a village road to yadnya as custom ceremony. Furthermore, it was told that the Calonarang envoys appeared, it performed by female dancers as representations of evil spirits towards the custom ceremony.

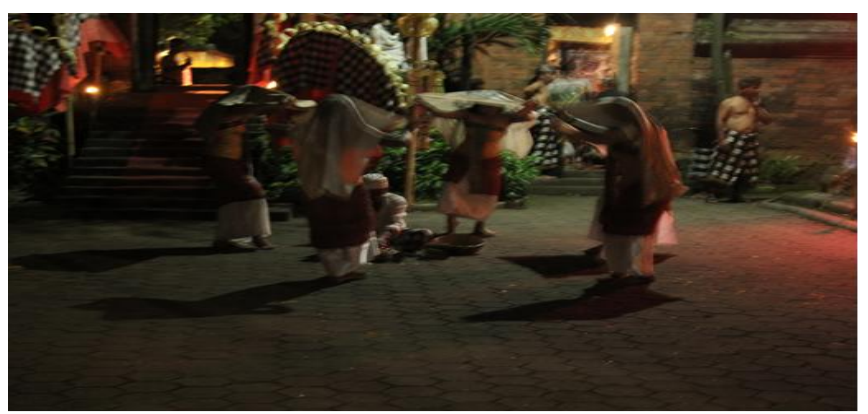

Photo 10. Calonarang Envoys and Temple Priest (Doc. Ruastiti, 2009). 
In photo 10 above, it can be observed about the scene of cheerfully as an expression of excitement over the custom ceremony has been carried out by the temple priest. The excitement from the Calonarang envoys ended and rushed away after the Gamelan and Tektekan voiced loud noise.

Scene II: The advisors of the Erlangga Kingdom with a sad expression about the state of fear of the people because the plague. Meanwhile, the dancers as Calonarang envoys appeared suddenly carrying gifts for Erlangga.

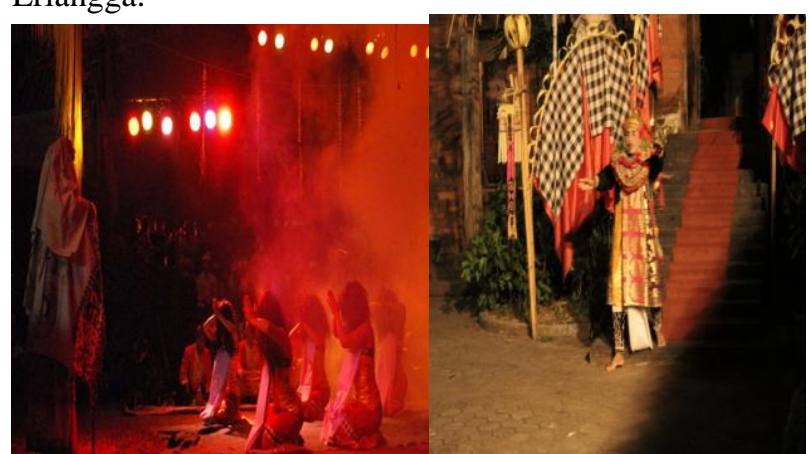

Photo 11. Calonarang, Calonarang Envoys as Represents Her Power and Erlangga

(Doc. Ruastiti, 2013).

Based on photo 11 above, the readiness of the Calonarang envoys in presenting gifts to the kingdom, especially for Erlangga's willingness to meet with the royal courtiers. However, the offering of the gift was rejected by the king's advisors. The refusal of the prize was carried out after knowing the bad intentions of Calonarang behind the offering. Therefore, the king's advisors immediately expelled Calonarang's envoys.

Scene III: The royal retainer facing the Pandung Maguna. He received the report immediately headed to the center of the Erlangga kingdom.

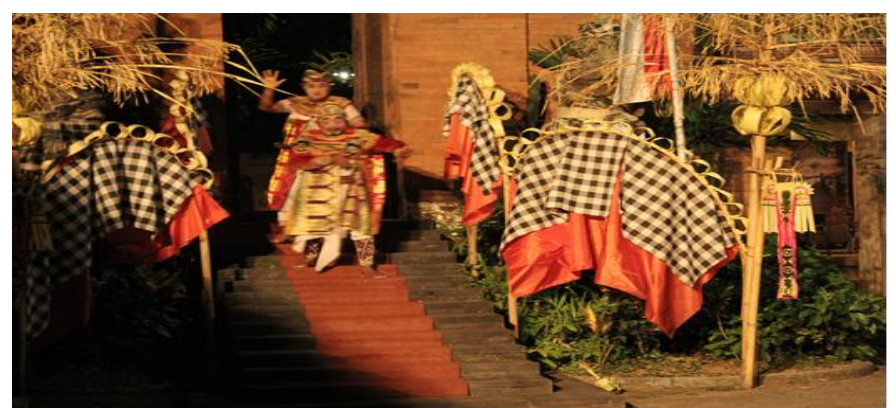

Photo 12. The Royal Retainers

(Doc. Yoga, 2009).

Scene IV: Ratna Manggali appears. Pandung Maguna begged respectfully that princess of Ratna Manggali would meet her mother. Ratna Manggali felt sad and refused the request. Pandung Maguna as the royal retainer was angry, forcibly dragged Ratna Manggali and tied her in the center of the kingdom.
Scene V: The bound tears of Ratna Manggali were heard by her mother, Calonarang. Celuluk was Calonarang envoy as a manifestation of the magic power for find and save her child.

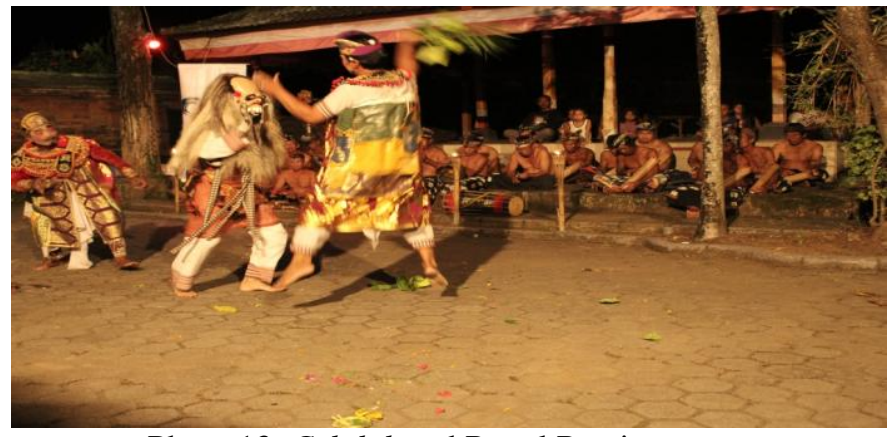

Photo 13. Celuluk and Royal Retainers

(Doc. Ruastiti, 2009).

In photo 13 above, the celuluk resistance scene against the royal retainer. Celuluk's resistance was carried out after the Celuluk managed to release the rope of Ratna Manggali's ties to the kingdom and wipe out his sadness. The damage and mischief of the kingdom due to Celuluk action made the courtiers try to surround and continue to attack. Finally, Celuluk was defeated and secured. By knowing the news of Celuluk's defeat, Calonarang change in revolution ary her self into Rangda. Rangda is a form of Calonarang's accumulation of the mysterious magical power, anger and bad intentions for the royal court over the treatment of her daughter.

Scene VI: Rangda did not directly attack the kingdom of Erlangga, but she attacked and persecuted a lot of villager as a form of anger over the Erlangga Kingdom by using magic power. A lot of resistance was carried out by the villager with keris and royal troops, but all lost and injured because of the magic powers of Calonarang. Many villager are said to be victims and Erlangga's royal forces die in vain. This situation began to change after the Maguna as the royal retainer of the Erlangga Kingdom has been successful involving Barong Ket to save innocent villager.

Scene VII: Barong Ket was present as a symbol of the enforcement of collective truth and virtue attacking Rangda as a symbol of error, crime and collective misery.

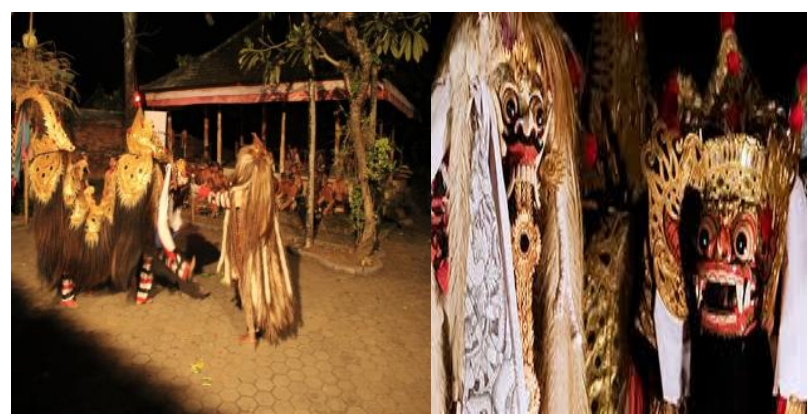

Photo 14. Rangda and Barong

(Doc. Yoga, 2013). 
Based on photo 14 above, can be known about the manifestations of Barong Ket and Rangda. Rangda as the embodiment of Calonarang was defeated by Barong Ket. Rangda, who has been defeated is then kicked out by penabuh, so that the life of villager can live in peace. Tektekan attractions close from the offering of Pre-Dinner Entertainment. The end of Tektekan attraction is the beginning of the stage of Entertaining During Dinner.

\section{Entertainment During Dinner}

Entertainment During Dinner was held at Jaba Tengah Puri for 90 minutes. For 90 minutes, tourists are presented with cultural tourism attractions articulated from various cultural symbols in the food procession, rindik melodies and joged bumbung dance. Power is always articulated in knowledge [8]. Various cultural symbols in the implementation of entertaining during dinner are authority represetations of the palace as a tourist in determining and regulating the components of cultural tourism attractions during dinner. Babi guling, lawar and Balinese traditional dishes in the dinner procession are offered by the dancers to each of the tourist tables by dancing. With the accompaniment of traditional Balinese innstruments, male dancers who wore masks performed dance moves by bringing babi guling bolsters around to the tourists' table followed by female dancers carrying traditional tabanan foods.

During the food procession performed by the dancers, the atmosphere and dance movements are decorated by the bamboo music called rindik. Rindik's melodies in Entertaintment During Dinner as the highlight of The Royal Dinner Party Puri Anyar Kerambitan Tabanan. Specifically, the rindik voice is intended to accompany the performance of joged dance in Entertaintment During Dinner.

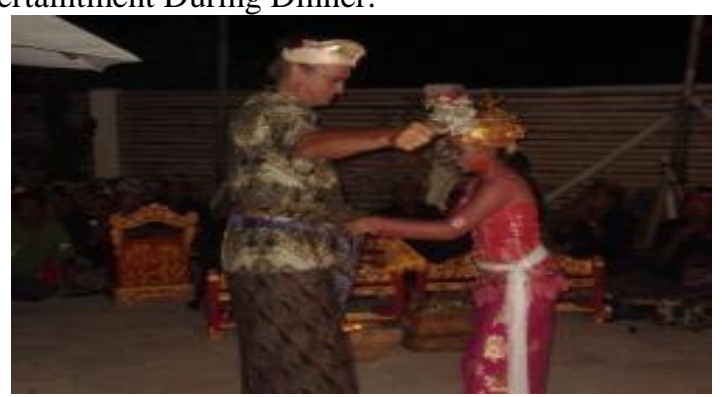

Photo 15. Joged Dance at The Royal Dinner Party Puri Anyar Kerambitan Tabanan

(Doc. Yoga, 2009).

Based on photo 15 above, the implementation of joged dance which is performed agile as Entertaintment During Party. The joged dance is performed by a female dancer in Balinese clothes along with guests, who are willing to dance with her. In addition to the accompaniment of rindik sounds, the interaction between the three female dancers and the guests in ngibing looks familiar, flexible and attractive because the sound of musical accompaniment from 4 gerantang besar, 4 gerantang kecil, 1 gong kemodong, 1 keleneng, 1 pangkan ricik, 1 medium-sized of kendang, 3 flutes and tawa-tawa. The atmosphere of intimacy through the implementation of the joged bumbung dance in Entertaintment During Dinner at The Royal Dinner Party Puri Anyar Kerambitan Tabanan lasted for 15 minutes.

Organizing power always produces something as a source for powers [3]. The joged dance performance for tourism is a cultural tourism attraction of Puri Anyar Kerambitan Tabanan which has been successfully fostered in order to strengthen the relationship with the community of scourges. For 15 minutes, tourists are presented with a spectacle of joged dance as Entertaintemt During Dinner event. After dinner is finished accompanied by the end of the rindik attraction is the stage where the tourists move to the bus.

\section{Entertaintment After Dinner}

During the process of the tourists to the bus, displayed an after dinner entertaintment from the Balaganjur attraction as a form of final respect to the special guests of the Kerambitan kingdom, Tabanan. The realization of respect through Balaganjur attractions can contribute to building a positive image for establishing the structure of social power. Power can be maintained and streamlined through the formation of good image for power holders [24]. Thus the holder of power can optimize social capital in the practice throught implementing cultural tourism attractions Puri Anyar Kerambitan Tabanan.

In Entertaintment After Dinner, a Balaganjur attraction was presented as the last cultural attraction from the Royal Dinner Party Puri Anyar Kerambitan Tabanan. Cultural tourism attractions were displayed lively in the central Jaba area of Puri Anyar Kerambitan Tabanan after Entertaintment During Dinner.

\section{B. Impact Of The Royal Dinner Party at Puri Kerambitan, Tabanan.}

The implementation of the Royal Dinner Party Puri Anyar Kerambitan Tabanan has economic implications, revitalization of patron client and sekaa as local community, increasing the motivation of Tabanan community members to become tourism perpetrator and preservation of Balinese culture in Tabanan.

\section{a. Economy}

The Royal Dinner Party Puri Anyar Kerambitan, Tabanan is a grand event. It has implications for improving the economic conditions of the Kerambitan community through involvement as a tourist in Puri Anyar Kerambitan, Tabanan. The amount of Puri Anyar Kerambitan need for the involvement of tourism actors in the success of The Royal Dinner Party Puri Anyar Kerambitan Tabanan gave a very broad opportunity for the Kerambitan community, Tabanan. Opportunities in the form of distribution of financial rewards 
and opportunity rotation as tourism actors are managed equally by the Puri Anyar Kerambitan family based on the templates and competencies as tourism actors, who have been mastered during the consolidation of the preparation in The Royal Dinner Party Puri Anyar Kerambitan Tabanan. Especially, the lack of economic demands for members of the Kerambitan community, Tabanan as a prerequisite for preparation of The Royal Dinner Party Puri Anyar Kerambitan Tabanan. It is very promising for the welfare of members of the Kerambitan community,Tabanan. Through such opportunities and compensation patterns, Kerambitan community members involved as perpetrators want to feel more possessed, strengthen the internalization of Puri Kerambitan's cultural values. They are willing to give consent to the subordination of their position. The social practice is line with the form of power management [18]. It is very capable of generating knowledge as capital for the strengthening of power and social position.

Hegemony can be said to be successful when the people is controlled already feels ownership and internalization of the values and norms of the authorities. They are willing to give supremacy or domination of the social class position on the basis of consensus intellectual and moral leadership [5]. By consensus, members of the Kerambitan community as tourism agents are expected to know, respect, master and carry out the work provided by the family of Puri Anyar Kerambitan Tabanan with conformist. The aspect of disensus from tourism practices requires the ability of tourism actors to be able to contradictory and disagree with the anticultural tourism movement. In other words, through the implementation of The Royal Dinner Party Puri Anyar Kerambitan Tabanan has implications for restoring the position of Puri Anyar Kerambitan Tabanan as a cultural center and strengthening the transformative form of palace as a productive field through cultural tourism activities in order to empower members of the Kerambitan community amid social changes in Tabanan. The manifestation of knowledge discourse can establish a hierarchy of power [21].

\section{b. Revitalization of Patron Client and Sekaa}

The implementation of The Royal Dinner Party Puri Anyar Kerambitan Tabanan because initiative of Anak Agung Oka Silagunada as the elder of Puri Anyar Kerambitan Tabanan in order to maintain patron client relationships between Puri Anyar Kerambitan and the Kerambitan community amid social changes in Tabanan. The effort was considered important by the Puri Anyar Kerambitan Tabanan family amid the increasingly weak dependency relations of the Kerambitan community with Puri Anyar Kerambitan accompanied by deterioration of the Puri Anyar Kerambitan Tabanan existence amid social life. Therefore, the Puri Anyar Kerambitan Tabanan family agreed and took the initiative to open access by prioritizing Kerambitan community members as tourists in The Royal Dinner Party Puri Anyar Kerambitan Tabanan with the theme of welcoming the royal guests in order to change the fate of the social position existence of Puri
Anyar Kerambitan Tabanan. As power and knowledge relations can change conditions [17].

The existence of Puri Anyar Kerambitan Tabanan is socially revitalized along with the successful appearance of cultural tourism attractions in The Royal Dinner Party. The implementation of The Royal Dinner Party is expected to strengthen the relationship of trust in the Kerambitan community towards Puri Anyar Kerambitan Tabanan. The cultural characteristics of Puri Anyar Kerambitan Tabanan are highly emphasized in the structural component of the implementation of The Royal Dinner Party Puri Anyar Kerambitan Tabanan which was designed by Anak Agung Oka Silagunada through various cultural symbols that are familiar in the culture of local traditional communities. Signified is expressed through a signifier to express meaning [9]. The manifestation of the Puri Anyar Kerambitan Tabanan culture is handled directly by the Puri Anyar Kerambitan Tabanan elders in order to emphasize the authenticity aspect of cultural attractions for tourism. The elder of Puri Anyar Kerambitan Tabanan as the organizer of the tourism event has full power in placing the attributes of the palace culture as a manifestation of the power of knowledge in cultural tourism attractions in the interests of Puri Anyar Kerambitan Tabanan. The exercise of power produces knowledge is needed as a strengthening of the power base [12]. The articulation of various symbolic components in the cultural tourism attraction of Puri Anyar Kerambitan Tabanan also confirms the power effect in converting cultural capital and diversification of tourism products as for the total performance of The Royal Dinner Party Puri Anyar Kerambitan Tabanan.

To be able to show a quality cultural tourism attraction, the Puri Anyar Kerambitan Tabanan family tried to foster the Balinese arts at Kerambitan, Tabanan in preparation for The Royal Dinner Party. As carried out coaching the composition of dance performances, musical accompaniment, the presentation of traditional food and foreign language training for prospective actors in the Royal Dinner Party Puri Anyar Kerambitan, Tabanan. The frequent implementation of The Royal Dinner Party Puri Anyar Kerambitan has resulted in the improvement of the relationship of continuous depedency between the Kerambitan community and the Puri Anyar Kerambitan Tabanan. Continuous dependency is needed in affirming hegemonic classes [1]. Structurally, sustainable depedency is needed in institutional sustainability.

It is interesting to note that Puri Anyar Kerambitan Tabanan's activities outside the tourism sector also received a positive response from the community. Thus, it's not a few of the members of the Kerambitan community make Puri Anyar Kerambitan Tabanan back as a centre in community activities. This means that with the accommodation of Kerambitan's community needs in the midst of efforts to endure patron client relation and institutional arts, the Puri Anyar Kerambitan Tabanan has contributed to maintaining the function of palace for indigenious social empowerment.

c. Increasing Motivation of Members of the Kerambitan, Tabanan Community as Tourist Actors 
The Royal Dinner Party Puri Anyar Kerambitan Tabanan has become a moment which provides a great opportunity for Kerambitan community members to become tourism actors. Great opportunity for the Kerambitan community as tourism actor because the initiative and cooperation from the relatives of Puri Anyar Kerambitan Tabanan, who are tasked with preparing carefully the tourism event at Puri Anyar Kerambitan Tabanan. As the task in handling the procession of the event is handled by Abdi Dalem Puri, the task of procuring tourist attractions is still handled by three relatives of Puri Anyar Kerambitan Tabanan in arranging decorations, structure of tour performances up to coordinating the arts and the task of maintaining the security of the event handled by Kerambitan people, who had obtained the mandate from Puri Anyar Kerambitan, Tabanan. So that, the offer as a tourist in The Royal Dinner Party was attracted by many considering that, most members of the Kerambitan community were well acquainted with those responsible for The Royal Dinner Party. Family relations, trust, experience and knowledge about culture become keys in opening opportunities for become tourism actors and gaining access to power in managing tourism activities at Puri Anyar Kerambitan, Tabanan. Supremacy of power requires relationships and knowledge [8].

The Royal Dinner Party as a result of Palace's power turned out to be very motivating for members of the Kerambitan community to become tourism actors. They often get praise and special recognition from Puri Anyar Kerambitan Tabanan as a form of cultural appreciation to members of the Kerambitan community. In hegemonic relationships, prizes can bring common sense to the availability of practices, even eliminate social oppression [5]. Members of the Kerambitan community as tourists can also fulfill their work voluntarily and steadily in accordance with the institutional ideal of the Puri Anyar Kerambitan Tabanan family. Every application of power correlates with the source of truth [8].

The effectiveness of the application of power is indicated by discretion. Discretion can be in the form of attitude stability including a combination of elements of sincerity, motivation, enthusiasm that affect the certainty of goals based on certain characteristics [15]. The discretion of Kerambitan community members as prospective tourism actors can produce experience to improve skills in the field of tourism through training and coaching members of the Kerambitan community related to the organization of The Royal Dinner Party Puri Anyar Kerambitan Tabanan. Therefore, it's not a few local families support the involvement of their siblings in the preparation phase to the implementation of the event in the hope of further improving the level of welfare of their lives. Likewise, there is an the arts interest as an unit of local community of Kerambitan to succeed The Royal Dinner Party Puri Anyar Kerambitan because it has high hopes of rotating the selection of tourism actors by the Puri Anyar Kerambitan Tabanan family. The power effect of knowledge is championed by the agent to achieve the goal [19]. As the opportunity obtained by
Kerambitan community members as tourism agents is always welcomed enthusiastically as a form of stability in the involvement of The Royal Dinner Party Puri Anyar Kerambitan Tabanan because it can have implications in increasing the prestige of social groups based on the community of Kerambitan, Tabanan.

\section{d. Preservation of Balinese Culture}

The implementation of The Royal Dinner Party Puri Anyar Kerambitan, Tabanan has contributed to the preservation of Balinese culture in the tourism sector. The form of preservation of Balinese culture was uil ton tourist attractions at the Royal Dinner Party Puri Anyar Kerambitan, Tabanan which has developed the cultural tourism potential of Puri Anyar Kerambitan, Tabanan. The culinary attractions use traditional Balinese foods and art attractions that use a variety of traditional Balinese performances complete with traditional Balinese music. The sound of traditional Balinese music collaborates with the uniqueness of traditional Balinese architecture from Puri Anyar Kerambitan, Tabanan combines symbolically and integrally as a Puri Anyar Kerambitan Tabanan cultural tourism attraction.

Articulative meaning can manifest through various symbolic expressions [9]. The articulation of the meaning of the order signification in the cultural tourism attraction of Puri Anyar Kerambitan Tabanan associatively repositioned the series of royal guest reception culturally not only for kings' relatives but also for tourists through the implementation of the Royal Dinner Party Puri Ayar Kerambitan Tabanan. Thus, the mediation of the attitude of tourism actors is ideologically expected to impact the revitalization of social trust in Puri Anyar Kerambitan as a cultural center.

All stage of The Royal Dinner Party Puri Anyar Kerambitan Tabanan as cultural tourism are coordinated and handled directly by the Puri Anyar Kerambitan family along with tourism partners in upholding the authority of Puri Anyar Kerambitan Tabanan and accommodating the needs of the Kerambitan community. Therefore, the contribution of The Royal Dinner Party was very much felt by the people of Kerambitan and the Puri Anyar Kerambitan family as tourism participant. With the frequent, The Royal Dinner Party Puri Anyar Tabanan Kerambitan held conformistly among the actors has implications for strengthening the form of Balinese cultural preservation in Puri Anyar Kerambitan Tabanan. Cultural preservation efforts in Puri Anyar Kerambitan Tabanan are now not only representative of local customs activities but can also be carried out through cultural tourism activities.

The phenomenon of Royal Dinner Party Puri Anyar Kerambitan Tabanan Scourge for tourism has become a new myth in cultural preservation practices at Tabanan. Doctrine that emphasizes that cultural preservation can be carried out outside the realm of culture. In that case, there is a new form of absolute knowledge that is able to limit and deny oppression and reduce effect of power that is violent. It shows that, there are special power actions related to social religiosity. They are beneficial for institutional cultural 
preservation practices. Generally, power is described as oppressive and restrictive [20].

Actions that influence changes in social practices based on the construction of absolute knowledge in certain social groups show succession of hegemony [1]. In other words, the characteristics of the hegemony power in the practice of The Royal Dinner Party Puri Anyar Kerambitan Tabanan are not only conformist in tourism activities but can be confirmed as conformists in the context of Balinese cultural preservation activities in Kerambitan, Tabanan.

\section{CONCLUSIONS}

The development of Bali Tourism has become a magnet for local communities in terms of the opportunities given by Puri Anyar Kerambitan Tabanan for creativity, preserving culture and gaining profits on the arrival of tourists in The Royal Dinner Party. Based on the results of an analysis of research on the Royal Dinner Party Puri Anyar Kerambitan Tabanan for tourism, it can be emphasized that :

1) The Royal Dinner Party Puri Anyar Kerambitan Tabanan is managed by Puri Anyar Kerambitan Tabanan partisipan for tourism purposes through the form of dinner parties based on local wisdom in Puri Kerambitan, Tabanan. The tourists who came to Puri Anyar Kerambitan Tabanan in the framework of The Royal Dinner Party were welcomed like royal guests. The tourists are invited to enjoy dinner at Puri Anyar Kerambitan Tabanan through a variety of traditional Balinese food accompanied by a series of cultural attractions.

2) Implementation of The Royal Dinner Party Puri Anyar Kerambitan Tabanan has economic implications, revitalization of patron client relations and mutual reinforcement, increasing the motivation of sekaa and Kerambitan community members to become tourism actors and preservation of Balinese culture in Tabanan.

\section{REFERENCES}

[1] Anderson, Perry, The Antinomies of Antonio Gramsci, London : Verso, 2017.

[2] Asa, Arthur Berger, Bali Tourism, USA and Canada : Haworth Press, 2013.

[3] Ball, S. (Ed.), Foucault and Education : Disciplines and Knowledge, London : Routledge, 2013.

[4] Cross, Hillary De and Bob Mc Chrecher, Cultural Tourism, 2nd Edition, UK : Taylor and Francois Ltd, 2015.

[5] Chun, Christian W., The Discourse of Capitalism : Everyday Economist and The Production of Common Sense, New York : Routledge, 2017.

[6] Creswell, J.W., Research Design : Qualitatif, Quantitatif And Mixed Methods Approaches, Thousand Oaks-CA : Sage Publication, 2013.

[7] Fabiani, Jean-Louis, Pierre Bourdieu : Un Structuralis-me Heroique, Paris : Seuil, 2016.

[8] Fejes, Andreas, The Confessing Society: Foucault, Confession and Practices of Lifelong Learning, Hoboken : Taylor and Francis, 2013.

[9] Ficacci, Luigi, Bacon : 1909-1992 : Deep Beneath The Surface of Things, Koln : Taschen, 2015.

[10] Hanna, Willard, A Brief History Of Bali : Piracy, Slavery, Opium and Guns (The History Of an Island Paradise), China : Tuttle, 2016.

[11] Jordan, Catheleen and Chynthia Franklin, Clinical Assesment For Social Workers : Quantitative And Qualitative Methods (Fourth Edition), UK : Oxford University Press, 2016

[12] Lucas, Adam, Ecclesiastical Lordship, Seigneurial Power And The
Commersialization Of Milling In Medieval England, New York : Routledge, 2016.

[13] Melampus, Sigmund Black, Primitive Materialism (Part One Of Immortality) : The Groundwork To The History Of Western Consciousness, England : Black's Academy, 2018.

[14] Miller, Chyntia Idris, The Ekstrem Gone Mainstream : Commersialitation and Far Right Youth Culture In Germany, USA: Princeton University Press, 2017.

[15] Peppiatt, Michael, Francois Bacon In Your Blood : A Memoir, London and New York : Bloomsbury Publishing, 2015.

[16] Pradana, Gede Yoga Kharisma and Wayan Pantiyasa, "Makotek As Tourist Attraction In Munggu Village, Bali", The $2^{\text {nd }}$ International

Conference On Tourism, Gastronomy and Tourist Destination, Jakarta : Atlantis Press, vol. 52 (5), 2018, pp 1-10, unpublished.

[17] Pradana, Gede Yoga Kharisma, "Innovation in Cenk Blonk Performance : A Strategy Of Empowering Local Language Through Balinese Shadow Puppet", International Conference On Local Language, Denpasar : UNUD Press, vol 1, 2018, pp 173-181, unpublished.

[18] Pradana, Gede Yoga Kharisma, "Deconstruction Power Relations Behind The Shadow Puppet Performance For Tourism In Ubud Village", Building Collaboration and Network in The Globalized World, Denpasar : UNUD Press, vol 1, 2017, pp 115-124, unpublished.

[19] Pradana, Gede Yoga Kharisma, "The Meaning Of Makotek Tradition At Munggu Village On Global Era”, International Bali Hinduism, Tradition and Intereligious Studies, Denpasar : UNHI Press, Vol.1, 2018, pp 1-12, unpublished.

[20] Pradana, Gede Yoga Kharisma, I Nyoman Suarka, A.A. Bagus Wirawan, I Nyoman Dhana, "Religious Ideology Of The Tradition Of Makotek In The Era Globalization", Electronic Journal Of Cultural Studies, Vol 9 (1), I Ketut Ardhana et.al. (ed), Denpasar : UNUD Press, 2016, pp 6-10.

[21] Pradana, Gede Yoga Kharisma, 2013, "Diskursus Fenomena Hamil Di Luar Nikah Dalam Pertunjukan Wayang Joblar", Online Journal Of Cultural Studies, Vol 1(1), Denpasar : UNUD Press, 2013, pp 11-27.

[22] Ruastiti, Made, Seni Pertunjukan Pariwisata Bali Kemasan Baru Dalam Perspektif Kajian Budaya, Yogyakarta : Kanisius, 2010.

[23] Smith, Melanine K., Issues In Cultural Tourism Studies, Third Edition, UK : Taylor and Francois Ltd., 2015.

[24] Tittenbrun, Jacek, Concepts of Capital: The Commodification of Social Life, New York : Routledge, 2017.

[25] Uhi, Jannes Alexander, Hatuhaha Amaria Lou Nusa Dalam Perspektif Filsafat Kebudayaan Cornelis Van Peursen Dan Relevansinya Dengan Keutuhan Bangsa Yogyakarta : Studi Pada Masyarakat Adat di Pulau Haruku, Maluku Tengah. Yogyakarta : Fakultas Filsafat UGM, 2014, unpublished.

[26] Van Peursen, Cornelis Anthonie, Strategi Kebudayaan, Yogyakarta : Kanisius, 2000. 